\title{
Biochemical effects of urapidil on red cell membrane ion transport systems in a population of elderly essential hypertensives
}

\author{
R. Antonicelli, E. Balducci, G. Lipponi' ${ }^{1}$ C. Lucantoni' ${ }^{1}$, R. Gaetti' and \\ E. Paciaroni. \\ Cardiovascular Laboratory and ${ }^{1}$ Department of Geriatric Medicine, Istituto I.N.R.C.A., Via Della \\ Montagnola 164, 60100 Ancona, Italy
}

\begin{abstract}
Summary: The aim of our work was to verify the effect of urapidil on membrane ion transport systems. This was a randomized, double-blind, cross-over study which evaluated the clinical and biochemical effects of urapidil ( $30 \mathrm{mg}$ twice daily in comparison with placebo) in a group of 10 elderly hypertensive patients ( 3 male, 7 female ranging from 68 to 90 years, mean age $79.2 \pm 7.6$ years). For the evaluation in fresh erythrocytes of principal ion transport systems (cotransport $\mathrm{Na}^{+} / \mathrm{K}^{+}$, countertransport $\mathrm{Na}^{+} / \mathrm{Li}^{+}, \mathrm{Na}^{+} / \mathrm{K}^{+}$ATPase pump. intracellular $\mathrm{Na}^{+}$and $\mathrm{K}^{+}$) we used the nystatin technique. We found that urapidil activated the red cell membrane ions cotransport system (basal values: $83.7 \pm 50.3 \mu \mathrm{mol} \mathrm{Na}{ }^{+} \mathbf{R B C ~}^{-1} \cdot \mathrm{h}^{-1}$, after 1 month of urapidil therapy: $181.5 \pm 89.3 \mu \mathrm{mol} \mathrm{Na}^{+} \mathbf{R B C}$ $\left.1^{-1} . h^{-1}\right)(P<0.01)$, without significant changes in the other biochemical parameters evaluated.

Our data suggest that one of the mechanisms of the urapidil antihypertensive effect could involve an increase in the membrane sodium cotransport system.
\end{abstract}

\section{Introduction}

Urapidil is a new once-daily antihypertensive drug $^{1-3}$ whose known mechanism is a balanced action between a peripheral alpha-1-postsynaptic adrenoreceptor block and a reduction of central sympathetic tone. ${ }^{4-6}$ According to pharmacodynamic studies ${ }^{7-11}$ it causes a reduction in total peripheral resistance, has no negative inotropic effects on the heart and does not cause any reflex increase in the sympathetic nervous system activity.

In spite of reduced arterial pressure, renal blood flow is maintained, presumably due to dilatation of renal vessels. ${ }^{12,13}$ Other effects of urapidil can be observed in various biological systems such as platelet aggregation, but to date there is no evidence of its possible action on cellular ion transport systems. Many authors ${ }^{14-17}$ consider alteration of membrane ion transport systems, in particular at the kidney tubular cell level, ${ }^{18}$ to be involved in the pathogenesis of arterial hypertension (EAH). Since it is very difficult to study these abnormalities in the human kidney cells or vascular smooth muscle, most studies use red blood cells (RBC). Moreover there is important evidence ${ }^{18}$ that shows similar physiopathological mechanisms in ion transport systems between RBC and kidney tubular cells.

Correspondence: R. Antonicelli, M.D., F.I.C.A. Accepted: 22 October 1990
The aim of our work was to evaluate the effect of this drug on red cell membrane ion transport $\frac{\partial}{0}$ systems.

\section{Material and methods}

We designed a randomized, double-blind, crossover study in order to evaluate the biochemical and clinical effects of urapidil (30 mg twice daily) vs 을 placebo, in a group of 10 elderly patients ( 3 male, $7 \stackrel{3}{3}$. female ranging from 68 to 90 years, mean age $\frac{5}{5}$ $79.2 \pm 7.6$ years) affected by mild and moderate EAH (WHO stage I and II). The study design had a $ᄋ$ run-in period of 1 month; one month of random therapy (placebo or urapidil), a cross over and 음 another month of therapy.

At the beginning of the study, after 1 month of therapy, before the cross over and at the end, we N evaluated, in freshly collected peripheral blood $\%$ erythrocytes, the principal ion transport systems $N$ (cotransport $\mathrm{Na}^{+} / \mathrm{K}^{+}$, countertransport $\mathrm{Na}^{+} / \mathrm{Li}^{+}, \underset{\omega}{\mathrm{N}}$ $\mathrm{Na}^{+} / \mathrm{K}^{+}$ATPase pump, intracellular $\mathrm{Na}^{+}$and $\left.\mathrm{K}^{+}\right) \underset{2}{ }$ using the nystatin as ionophore to measure ion 0 transports in loaded RBC. ${ }^{19}$

\section{Preparation of red cells}

Early in the morning $30 \mathrm{ml}$ of venous blood was drawn into lithium-heparin tubes and immediately 
processed. Plasma and buffy coat were removed by cold centrifugation $\left(4^{\circ} \mathrm{C}\right)(3000 \times g$ for $15 \mathrm{~min}$ utes). The cells were twice rinsed $\left(4^{\circ} \mathrm{C}\right)$ with cold washing solution (WS) containing $110 \mathrm{mM} \mathrm{MgCl}_{2}$, $10 \mathrm{mM}$ Tris-mops, $\mathrm{pH}$ 7.4. Later, $1.5 \mathrm{ml}$ of packed red cells were used for each nystatin loading procedure and $1.8 \mathrm{ml}$ for lithium loading. The rest of the packed red cells were washed again and resuspended at $30 \%$ haematocrit in WS.

\section{Intracellular cation measurements}

Red cell suspension $(50 \mu \mathrm{l})$ was lysed in three tubes containing $10 \mathrm{ml}$ of distilled water each, to measure haemoglobin and cation content. The same dilution was used for $\mathrm{Na}^{+}, \mathrm{K}^{+}$, and $\mathrm{Li}^{+}$determination by atomic absorption spectrophotometer. Haemoglobin absorbance was stable during the loading procedure which indicates no appreciable swelling of cells.

\section{Cation efflux measurement}

Total $\mathrm{Na}^{+}$efflux was measured in a medium containing $6 \mathrm{mM} \mathrm{KCl}, 73 \mathrm{mM} \mathrm{MgCl}_{2}, 75 \mathrm{mM}$ sucrose, $10 \mathrm{mM}$ glucose and $10 \mathrm{mM}$ Tris-mops (pH 7.4). Ouabain and bumetanide-sensitive effluxes were processed in the same medium (without $\mathrm{KCl}$ ) containing $0.1 \mathrm{mM}$ ouabain and $20 \mathrm{mM}$ bumetanide freshly prepared in DMSO.

Both tubes were incubated at $37^{\circ} \mathrm{C}$ for 5,15 and 25 minutes in the first medium; 5,35 and 65 minutes (at the same temperature) in the second. To stop the reaction the tubes were placed at $4^{\circ} \mathrm{C}$ and then centrifuged at highest velocity for 1 minute at $4^{\circ} \mathrm{C}$ in a centrifuge.

The supernatant fluid was transferred in plastic tubes and stored at $4^{\circ} \mathrm{C}$ until cation content analysis (by a Pn 9000 Philips atomic spectrophotometer).

\section{Nystatin loading procedure}

The loading procedure was performed by the Canessa technique ${ }^{19}$ utilizing only two point loading. Packed red cells $(1.5 \mathrm{ml})$ were stored briefly at $4^{\circ} \mathrm{C}$ in a Falcon tube in presence of solution containing $20 \mathrm{mM} \mathrm{NaCl}, 120 \mathrm{mM} \mathrm{KCl}, 50 \mathrm{mM}$ sucrose and $90 \mathrm{mM} \mathrm{NaCl}, 50 \mathrm{mM} \mathrm{KCl}, 50 \mathrm{mM}$ sucrose, using nystatin as an ionophore twice for 20 and 10 minutes respectively). The cells were washed 4 times with solutions at the same concentration of $\mathrm{NaCl}, \mathrm{KCl}$ and sucrose for each loaded red cell sample but in the presence of $10 \mathrm{mM}$ glucose and $0.1 \%$ albumin $\left(\right.$ at $\left.37^{\circ} \mathrm{C}\right)$ to eliminate the ionophore. The external cations were removed by five washes with WS solution, and cells were resuspended at $30 \%$ haematocrit before processing for cation efflux measurement as previously described.

\section{Procedure for $\mathrm{Na}^{+} / \mathrm{Li}^{+}$countertransport}

Packed red cells were incubated at $37^{\circ} \mathrm{C}$ for 3 hours in a medium containing $150 \mathrm{mM} \mathrm{LiCl}, 10 \mathrm{mM}$ glucose and $10 \mathrm{~mm}$ Tris-mops (at $\mathrm{pH}$ 7.4). After incubation cells were washed with WS and incubated for 5, 20 and 35 minutes with and without high $\mathrm{Na}^{+}$concentration $(150 \mathrm{mM})$ for lithium effluxes and countertransport measurement. Samples were performed as previously described (using the same spectrophotometer).

\section{Statistical analysis}

Statistical analysis of the results was performed by use of repeated measure analysis of variance (MANOVA) evaluated under the different treatment groups.

The statistical package SPSS following the MANOVA procedure was used, a probability value of less than 0.05 was considered significant for the analysis statistical $F$ test.

\section{Results}

As regards the effect of urapidil on red cell membrane ion transports (Table I), we found a significant increase $(P<0.01)$ in the cotransport system.

The intracellular $\mathrm{Na}^{+}$and $\mathrm{K}^{+}$did not show significant modifications: $\mathrm{Na}^{+}$basal values $10.2 \pm 1.1 \mathrm{mmol} / \mathrm{l}$, after urapidil therapy: $10.8 \pm 1.5$, and after placebo $10.2 \pm 1.5 \mathrm{mmol} / 1$. $\mathrm{K}^{+}$basal levels $103.7 \pm 1.3 \mathrm{mmol} / \mathrm{l}$, after one month of active therapy $110.6 \pm 5.8 \mathrm{mmol} / \mathrm{l}$, and after placebo $113.1 \pm 3.7 \mathrm{mmol} / \mathrm{l}$. Also $\mathrm{Na}^{+} / \mathrm{Li}^{+}$ countertransport and $\mathrm{Na}^{+} / \mathrm{K}^{+}$ATPase pump do not show any significant modifications during urapidil therapy.

During the study we did not find any significant changes in the other biochemical parameters evaluated.

ANOVA for repeated measures indicated no significant overall carry-over effect for any parameter and allowed for an analysis of treatment effect.

There were no significant side effects or changes on haematological or biochemical values.

\section{Discussion}

Although excess $\mathrm{Na}^{+}$intake has been identified as one of the major pathogenetic factors in many patients with EAH, its real role still remains obscure. Many observations $s^{15,16,18}$ of different sodium transport abnormalities in erythrocytes from patients with EAH suggest that the link between 
Table I Biochemical effects of urapidil on red blood cell main ion transport systems

\begin{tabular}{|c|c|c|c|}
\hline & \multirow{2}{*}{$\begin{array}{c}\text { Before treatment } \\
\text { Baseline }\end{array}$} & \multicolumn{2}{|c|}{ After treatment } \\
\hline & & Urapidil & Placebo \\
\hline $\begin{array}{l}\mathrm{Na}^{+} / \mathrm{K}^{+} \mathrm{CT} \\
\left(\mu \mathrm{mol} \mathrm{Na} \mathrm{Na}^{+} \mathrm{RBC} 1^{-1} \cdot \mathrm{h}^{-1}\right)\end{array}$ & $83.7 \pm 50.3$ & $181.5 \pm 89.3^{*}$ & $50.0 \pm 29.4$ \\
\hline $\begin{array}{l}\mathrm{Na}^{+} / \mathrm{Li}^{+} \mathrm{CNT} \\
\left(\mu \mathrm{mol} \mathrm{Na} \mathrm{Na}^{+} \mathrm{RBC} 1^{-1} \cdot \mathrm{h}^{-1}\right)\end{array}$ & $301.6 \pm 123.0$ & $251.3 \pm 135.6$ & $280.8 \pm 97.9$ \\
\hline $\begin{array}{l}\mathrm{Na}^{+}(\mathrm{i}) \\
(\mathrm{mmol} / \mathrm{l})\end{array}$ & $10.2 \pm 1.0$ & $10.8 \pm 1.5$ & $10.2 \pm 1.5$ \\
\hline $\begin{array}{l}\mathrm{K}^{+}(\mathrm{i}) \\
(\mathrm{mmol} / \mathrm{l})\end{array}$ & $103.7 \pm 1.3$ & $110.6 \pm 5.9$ & $113.0 \pm 3.7$ \\
\hline
\end{tabular}

*P<0.01; CT: cotransport; CNT: countertransport; (i): intracellular.

sodium and hypertension could be a disorder of $\mathrm{Na}^{+}$handling by the kidney, by vascular smooth muscle cells and by other possible cells involved in hypertension pathogenesis.

In relation to EAH the most studied membrane ion transport systems are $\mathrm{Na}^{+} / \mathrm{Li}^{+}$countertransport, $\mathrm{Na}^{+} / \mathrm{K}^{+}$ATPase pump and $\mathrm{Na}^{+} / \mathrm{K}^{+}$cotransport. The alterations of these membrane ion transport systems may play an important role in $\mathrm{Na}^{+}$handling, in particular $\mathrm{Na}^{+} / \mathrm{Li}^{+}$countertransport abnormalities which could reflect an increased renal sodium reabsorption. ${ }^{18}$ Conversely, the decrease of apparent affinity of the $\mathrm{Na}^{+} / \mathrm{K}^{+}$ pump for internal $\mathrm{Na}^{+20}$ may reflect an abnormal regulation of the increase in cell $\mathrm{Na}^{+}$content. Finally, recent observations underline the possibly important role of the cotransport system as a silent cellular 'second pump'. This process, in fact, is almost non-existent under physiological conditions, but can be unmasked by an increase in cell $\mathrm{Na}^{+}$content. ${ }^{21}$

In particular, the cotransport system (of vascular cells and/or noradrenergic endings) may play two different roles in EAH: as 'defective second pump' in some patients with decreased cotransport affinity for internal $\mathrm{Na}^{+}$, or as 'compensatory second pump' in others, where some abnormalities in the ion transport system may predispose the cell to a defective extrusion of excess cell $\mathrm{Na}^{+}$content. The cotransport system helps the $\mathrm{Na}^{+} / \mathrm{K}^{+}$ATPase pump in extruding any excess cell $\mathrm{Na}^{+}$content. ${ }^{21}$

On the other hand, an increased 'second pump'

\section{References}

1. Langtry, H.D., Mammen, G.J. \& Sorkin, E.K. Urapidil. A review of its pharmacodynamic properties, and therapeutic potential in the treatment of hypertension. Drugs 1989, 38: 900-940.

2. Rosendorff, C. Urapidil in the treatment of hypertension. Drugs 1988, 35: 188-192.

3. Trimarco, B., Rosiello, G., Feldhaus, P. et al. Efficacy of once-daily urapidil treatment in mild or moderate essential hypertension assessed by ambulatory 24-hour blood pressure monitoring. Drugs 1988, 35: 173-181. activity of the cotransport system may "compensate 3 other $\mathrm{Na}^{+}$transport abnormalities which predis- $-{ }^{-}$ pose the cell to an abnormal handling of any excess: - V cell $\mathrm{Na}^{+}$content. Recent studies show that in o patients with essential hypertension the values of cotransport has a characteristic bimodal distribu-N tion with low or high values. ${ }^{22}$

Our hypertensive patients are characterized by low cotransport. In such cases we believe that the $?$ cotransport can be a 'defective second pump' and $\stackrel{2}{\circ}$ that, in particular under a sodium load, the system $\stackrel{ }{\supset}$ cannot 'compensate' this abnormal sodium hang $\overrightarrow{0}$ ling. One of the possible consequences is a transie excess in $\mathrm{Na}^{+}$cell content, with a conseque increase of $\mathrm{Ca}^{++}$and a final vascular resistance increase. ${ }^{23}$ We think that urapidil activates, in these subjects, the cotransport which becomes more effective when handling excess $\mathrm{Na}^{+}$cell content, $\frac{\circ}{\varnothing}$

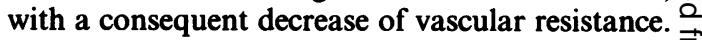
In other words we hypothesize that the peripheral $\stackrel{0}{\circ}$ antihypertensive effects of urapidil could not only be an alpha-1-postsynaptic block, but also direct action on the cotransport system, at least in those hypertensives with low cotransport values. We conclude that one of the mechanisms of the urapidil antihypertensive effect could involve an increase in $\exists$ the membrane $\mathrm{Na}^{+} / \mathrm{K}^{+}$cotransport system.

\section{Acknowledgement}

We are grateful to Dr Daniele Cusi for his criticism and technical supervision.

4. Shepherd, A.M.M. Human pharmacology of urapidil. Drugs 1988, 35 (Suppl. 6): 34-39.

5. Cubeddu, L.X. New alpha 1 -adrenergic receptor antagonistsco for the treatment of hypertension: role of vascular alpha $\frac{\bar{D}}{\Phi}$ receptors in the control of peripheral resistance. Am Heart $J$ 1988, 116: 133-162.

6. Van Zwieten, P. Antihypertensive drugs interacting with $T$ alpha and beta-adrenoceptors: a review of basic pharmacology. Drugs 1988, 35 (Suppl. 6): 6-19. 
7. Bielen, E., Fagard, R., Staessen, J., Lijnen, P., Van Hoof, R. \& Amery, A. Urapidil-induced hemodynamic changes in humans. Am J Cardiol 1989, 15: 16D-21D.

8. Bottorff, M.B., Hoon, T.J., Rodman, J.H., Gerlach, P.A. \& Ramanathan, K.B. Pharmacokinetics and pharmacodynamics of urapidil in severe hypertension. J Clin Pharmacol 1988, 28: 420-426.

9. Kirsten, R., Nelson, K., Neff, J., Harlin, R., Steinijans, V. \& Radtke, H.W. Pharmacodynamics and pharmacokinetics of three different doses of urapidil infused in hypertensive patients. Eur J Clin Pharmacol 1986, 30: 549-552.

10. Prichard, B.N.C., Renondin, J.C. \& Tomlinson, B. Clinical pharmacology of urapidil. J Hypertens 1988, 6 (Suppl. 2): S13-19.

11. Leonetti, G., Terzoli, L. \& Zanchetti, A. Systemic haemodynamic and humoral changes during urapidil treatment in hypertensive patients. J Hypertens 1988, 6 (Suppl. 2): S25-29.

12. De Leeuw, P.W., Van Es, P.N., De Bruyn, H.A. \& Birkenhager, W.H. Renal haemodynamic and neurohumoral responses to urapidil in hypertensive man. Drugs 1988, 35: 74-77.

13. Leonetti, G. Effects of alpha-adrenoceptor blockers on renal function and blood pressure adjustment in human hypertension. Drugs 1988, 35: 53-59.

14. Haddy, F.J. Abnormalities of membrane transport in hypertension. Hypertension 1983, 5 (Suppl. V): V-66-72.

15. Garay, R.P., Dagher, G., Pernollet, M.G., De Mendonca, R. \& Mayer, $\mathrm{P}$. Inherited defect in a $\mathrm{Na}^{+}, \mathrm{K}^{+}$, cotransport system in erythrocytes from essential hypertensive patients. Nature 1980, 284: 281-283.
16. Adragna, N., Canessa, M., Soloman, H. \& Tosteson, D.C. Red-cell lithium-sodium countertransport and sodium-potassium cotransport in patients with essential hypertension. Hypertension 1982, 4: 795-804.

17. Postnov, Y.V. \& Orlov, S.N. Ion transport across plasma membrane in primary hypertension. Physiol Rev 1985, 65: 904-945.

18. Weder, A.B. Red-cell lithium-sodium countertransport and renal lithium clearance in hypertension. $N$ Engl J Med 1986, 314: 198-201.

19. Canessa, M., Brugnara, C., Cusi, D. \& Tosteson, D.C. Modes of operation and variable stoichimetry of the furosemidesensitive $\mathrm{Na}^{+}$and $\mathrm{K}^{+}$fluxes in human red cells. $J$ Gen Physiol 1986, 87: 113-142.

20. Garay, R.P., Rosati, C. \& Meyer, P. $\mathrm{Na}^{+}$transport in primary hypertension. Ann NY Sci 1986, 488: 187-195.

21. Saitta, M.N., Hannaert, P.A., Rosati, C., Diaz, A.S., Senn, N. \& Garay, R.P. $\left[\mathrm{Na}^{+}, \mathrm{K}^{+}, \mathrm{Cl}^{-}\right]$cotransport function and dysfunction in different forms of primary hypertension. Am J Hypertens 1988, 1: 60S-63S.

22. Cusi, D., Alberghini, E., Barlassina, C. et al. Are high Na-K cotransport essential hypertensive patients a subpopulation with peculiar pathogenetic mechanism? Abs. 12th Scientific Meeting of the International Soc. of Hypertension, Kyoto, May 1988.

23. Blaustein, M.P. Sodium ions, calcium ions, blood pressure regulation and hypertension: a reassessment and a hypothesis. Am J Physiol 1977, 232: C165-173. 